\title{
ANALISIS JALUR (PATH ANALYSIS) PENGARUH KONDISI SOSIAL EKONOMI DAN MOTIVASI BELAJAR TERHADAP PRESTASI BELAJAR MAHASISWA
}

\author{
Desy Setyorini ${ }^{1}$, Achmad Syahlani ${ }^{2}$ \\ Fakultas Teknologi Informasi Program Studi Sistem Informasi \\ Universitas Bina Sarana Informatika \\ Jl. Kamal Raya No.18 Cengkareng, Jakarta Barat \\ desy.dse@bsi.ac.id ${ }^{1}$, achmad.acy@bsi.ac.id $^{2}$
}

\begin{abstract}
Abstrak - Tujuan dari penelitian ini adalah untuk menguji pengaruh langsung kondisi sosial ekonomi dan motivasi belajar terhadap prestasi belajar mahasiswa, serta pengaruh langsung kondisi sosial ekonomi terhadap motivasi belajar mahasiswa. Penelitian dilakukan di Institut Sains dan Teknologi Al-Kamal Jakarta dengan populasi penelitian adalah seluruh mahasiswa Program Studi Teknik Informatika, Fakultas Teknologi Informasi \& Komunikasi Visual. Dari populasi tersebut, diambil sampel sebanyak 70 mahasiswa yang diperoleh dengan menggunakan teknik pengambilan sampel acak sederhana. Penelitian ini menggunakan metode survei kausal. Data penelitian dijaring melalui instrumen penelitian berupa kuesioner dengan skala Likert, kemudian diolah dan dianalisis dengan teknik analisis jalur. Hasil penelitian ini menunjukkan bahwa: (1) Tidak terdapat pengaruh langsung kondisi sosial ekonomi terhadap prestasi belajar mahasiswa; (2) Terdapat pengaruh langsung motivasi belajar terhadap prestasi belajar mahasiswa; dan (3) Terdapat pengaruh langsung kondisi sosial ekonomi terhadap motivasi belajar mahasiswa.
\end{abstract}

Kata kunci: prestasi belajar, motivasi belajar, kondisi sosial ekonomi

Abstract - The purpose of this research is to test the direct effect of socioeconomic conditions and learning motivation on learning achievement of college student, and the direct effect of socioeconomic conditions on learning motivation of college student. This research was conducted at the Al-Kamal, Institute of Science and Technology, in Jakarta, where all students of the Informatics Engineering Study Program, Faculty of Information \& Visual Communication Technology as the population. From this population, a sample of 70 students was taken using simple random sampling. This research uses a causal survey method. The research data were obtained through questionnaire instrument with a Likert scale, then processed and analyzed with path analysis. The results of this research indicate that: (1) There is no direct effect of socioeconomic conditions on learning achievement of college student; (2) There is a direct effect of learning motivation on learning 
achievement of college student; and (3) There is a direct effect of socioeconomic conditions on learning motivation of college student.

Keyword: learning achievement, learning motivation, socioeconomic conditions

\section{PENDAHULUAN}

Sumber daya manusia yang berkualitas mutlak diperlukan untuk kemajuan bangsa dan negara. Salah satu upaya membina sumber daya manusia yang berkualitas adalah melalui pendidikan formal, mulai dari jenjang pendidikan dasar, menengah, hingga pendidikan tinggi.

Menurut pasal 3, Undang-Undang Nomor 20 Tahun 2003, pendidikan nasional berfungsi mengembangkan kemampuan dan membentuk watak serta peradaban bangsa yang bermartabat dalam rangka mencerdaskan kehidupan bangsa. Dalam pasal tersebut dijelaskan pula bahwa pendidikan nasional bertujuan untuk mengembangkan potensi peserta didik agar menjadi manusia yang beriman dan bertaqwa kepada Tuhan Yang Maha Esa, berakhlak mulia, sehat, berilmu, cakap, kreatif, mandiri, dan menjadi warga negara yang demokratis serta bertanggung jawab.

Perguruan tinggi sebagai penyelengara jenjang pendidikan tinggi diharapkan mampu menghasilkan lulusan yang berkualitas dan bermutu tinggi, sesuai dengan fungsi dan tujuan dari pendidikan nasional di atas. Namun dalam kenyataannya, perguruan tinggi banyak mengalami berbagai hambatan untuk memenuhi harapan tersebut. Salah satu hambatan yang berkaitan dengan peningkatan kualitas dan mutu pendidikan tinggi adalah masih rendahnya prestasi belajar mahasiswanya.

Ada banyak faktor yang dapat mempengaruhi prestasi belajar mahasiswa. Faktor-faktor tersebut dapat berasal dari dalam diri mahasiswa (internal) diantaranya minat, motivasi, dan tingkat kecerdasan intelektual maupun emosional, serta faktorfaktor yang berasal dari luar diri (eksternal) mahasiswa diantaranya kompetensi dosen, kualitas sarana-prasarana, dan kondisi sosial ekonominya.

Salah satu prinsip yang harus dijadikan pedoman dalam melaksanakan pendidikan yang baik adalah peserta didik harus secara aktif mengambil bagian dalam kegiatan pendidikan yang dilaksanakan. Untuk dapat secara aktif mengambil bagian dalam kegiatan belajar-mengajar diperlukan adanya dorongan atau motivasi dari peserta didik. Motivasi tersebut dapat berasal dari dalam diri peserta didik ataupun dari luar diri 
peserta didik. Motivasi yang kuat dapat mendorong peserta didik untuk lebih aktif dan berpartisipasi dalam mengikuti kegiatan belajar-mengajar.

Motivasi belajar memiliki peranan yang sangat penting dalam menggerakkan diri untuk mau mempelajari dan berusaha menguasai materi dalam setiap mata kuliah. Mahasiswa yang memiliki motivasi belajar yang tinggi akan melakukan kegiatan belajar dalam usahanya untuk memiliki penguasaan terhadap materi dalam setiap mata kuliah, yang ditunjukkan dengan perolehan nilai akhir yang tinggi. Dengan memiliki motivasi belajar yang tinggi, maka mahasiswa akan berusaha semaksimal mungkin untuk memperoleh prestasi belajar yang tinggi.

Faktor lain yang dapat mempengaruhi prestasi belajar mahasiswa, baik secara langsung maupun tidak langsung, adalah kondisi sosial ekonominya. Kondisi sosial ekonomi keluarga/orang tua erat hubungannya dengan proses belajar anak. Anak yang sedang belajar selain harus terpenuhi kebutuhan pokoknya, kebutuhan-kebutuhan lain yang diperlukan dalam proses belajar juga harus terpenuhi. Kebutuhan-kebutuhan tersebut akan dapat terpenuhi dengan baik jika keluarga/orang tuanya mempunyai kondisi sosial ekonomi yang baik pula.

Kondisi sosial ekonomi juga dapat mempengaruhi motivasi belajar mahasiswa. Kebutuhan-kebutuhan yang berkaitan dengan proses belajar mahasiswa yang berasal dari keluarga dengan kondisi sosial ekonomi yang lemah, cenderung kurang terpenuhi dengan baik, sehingga dapat mempengaruhi motivasi belajarnya menjadi rendah, akibat dari kebutuhan-kebutuhannya yang tidak terpenuhi dengan baik.

Institut Sains dan Teknologi Al-Kamal adalah salah satu perguruan tinggi swasta di Jakarta yang menyelenggarakan pendidikan tinggi melalui 8 program studi jenjang sarjana atau setara dengan pendidikan S1. Mahasiswanya berasal keluarga dengan kondisi sosial ekonomi yang berbeda-beda, sehingga motivasi dan prestasi belajar mahasiswanya cenderung akan berbeda-beda pula.

Berdasarkan uraian di atas, maka perlu dilakukan penelitian dengan permasalahan sebagai berikut:

1. Apakah terdapat pengaruh langsung kondisi sosial ekonomi terhadap prestasi belajar mahasiswa Institut Sains dan Teknologi Al-Kamal Jakarta?

2. Apakah terdapat pengaruh langsung motivasi belajar terhadap prestasi belajar mahasiswa Institut Sains dan Teknologi Al-Kamal Jakarta? 
3. Apakah terdapat pengaruh langsung kondisi sosial ekonomi terhadap motivasi belajar mahasiswa Institut Sains dan Teknologi Al-Kamal Jakarta?

\section{KAJIAN TEORI DAN HIPOTESIS PENELITIAN}

\subsection{Prestasi Belajar}

(Santrock,2004) mendefinisikan belajar sebagai "a relatively permanent influence on behavior, knowledge, and thinking skills, which comes about through experience." Pendapat yang sama dikemukakan oleh Woolfolk (2007:206) yang menyatakan bahwa "learning occurs when experience causes a relatively permanent change in an individual's knowledge or behavior." Kedua pengertian tersebut samasama menyatakan bahwa seseorang dikatakan telah belajar jika terjadi perubahan yang sifatnya relatif tetap dalam pengetahuan dan tingkah lakunya, yang diperoleh melalui pengalaman.

Belajar pada manusia dapat dirumuskan sebagai suatu aktivitas mental/psikis, yang berlangsung dalam interaksi aktif dengan lingkungan, yang menghasilkan sejumlah perubahan dalam pengetahuan-pemahaman, keterampilan, dan nilai-sikap. Perubahan itu bersifat secara relatif konstan dan berbekas. Perolehan perubahan itu dapat berupa suatu hasil yang baru atau pula penyempurnaan terhadap hasil yang telah diperoleh (Winkel, 2004).

Prestasi belajar pada hakekatnya merupakan hasil yang telah dicapai seseorang setelah melakukan usaha belajar. Pada umumnya semakin baik usaha belajar, maka akan semakin baik pula prestasi yang akan dicapai. Menurut (Sardiman, 2001) "prestasi belajar adalah kemampuan nyata yang merupakan hasil interaksi antara berbagai faktor yang mempengaruhi, baik dari dalam maupun dari luar individu dalam belajar", sedangkan menurut (Tu'u, 2004) “prestasi belajar adalah penguasaan pengetahuan atau keterampilan yang dikembangkan oleh mata pelajaran yang lazimnya ditunjukkan dengan nilai tes atau angka nilai yang diberikan guru".

Keberhasilan siswa dalam mencapai prestasi belajar dipengaruhi oleh beberapa faktor, yaitu tingkat kecerdasan yang baik, pelajaran sesuai dengan bakat yang dimiliki, ada minat dan perhatian yang tinggi dalam pembelajaran, motivasi yang baik dalam belajar, cara belajar yang baik dan strategi pembelajaran yang dikembangkan guru. Suasana keluarga yang mendorong anak untuk maju, lingkungan sekolah yang tertib, 
teratur, dan disiplin merupakan pendorong dalam proses pencapaian prestasi belajar (Tulus Tu`u, 2004).

Slameto (2010:54) mengemukakan bahwa faktor-faktor tersebut dapat dikelompokkan ke dalam dua jenis, yaitu:

1. Faktor-faktor intern

a. Faktor jasmaniah, meliputi faktor kesehatan dan cacat tubuh.

b. Faktor psikologis, meliputi faktor intelegensi, perhatian, minat, bakat, motivasi, kematangan, dan kesiapan.

c. Faktor kelelahan, meliputi kelelahan jasmanin dan kelelahan rohani.

\section{Faktor-faktor ekstern}

a. Faktor keluarga, meliputi cara orang tua mendidik, relasi antar anggota keluarga, suasana rumah, keadaan ekonomi keluarga, pengertian orang tua, dan latar belakang kebudayaan.

b. Faktor sekolah, meliputi metode mengajar, relasi guru dengan siswa, relasi siswa dengan siswa, disiplin sekolah, alat pelajaran, waktu sekolah, keadaan gedung, metode belajar, dan tugas rumah.

c. Faktor masyarakat, meliputi kegiatan siswa dalam masyarakat, mass media, teman bergaul, dan bentuk kehidupan masyarakat.

\subsection{Kondisi Sosial Ekonomi}

Keadaan sosial ekonomi setiap orang itu berbeda-beda dan bertingkat, ada yang keadaan sosial ekonominya tinggi, sedang, dan rendah.

Sosial ekonomi menurut (Abdulsyani,1994) adalah kedudukan atau posisi seseorang dalam kelompok manusia yang ditentukan oleh jenis aktivitas ekonomi, pendapatan, tingkat pendidikan, jenis rumah tinggal, dan jabatan dalam organisasi, berdasarkan beberapa pendapat diatas, dapat disimpulkan pengertian keadaan sosial ekonomi dalam penelitian ini adalah kedudukan atau posisi seseorang dalam masyarakat berkaitan dengan tingkat pendidikan, tingkat pendapatan pemilikan kekayaan atau fasilitas serta jenis tempat tinggal.

\subsubsection{Faktor-faktor yang menentukan keadaan sosial ekonomi.}

Berdasarkan kodratNya manusia dilahirkan memiliki kedudukan yang sama dan sederajatnya, akan tetapi sesuai dengan kenyataan setiap manusia yang menjadi warga 
suatu masyarakat, senantiasa mempunyai status atau kedudukan dan peranan. Ada beberapa faktor yang dapat menentukan tinggi rendahnya keadaan sosial ekonomi orang tua di masyarakat, diantaranya yaitu tingkat pendidikan, pendapatan, dan kepemilikan kekayaan, dan jenis tempat tinggal.

a. Tingkat Pendidikan

Jalur pendidikan sekolah (pendidikan formal) terdapat jenjang pendidikan sekolah, jenjang pendidikan sekolah pada dasarnya terdiri dari pendidikan prasekolah, pendidikan dasar, pendidikan menengah, dan pendidikan tinggi.

1) Pendidikan prasekolah.

Menurut PP No. 27 tahun 1990 dalam (Kunaryo,2000), pendidikan prasekolah adalah pendidikan untuk membantu pertumbuhan dan perkembangan jasmani dan rohani peserta didik di luar lingkungan keluarga sebelum memasuki pendidikan dasar, yang diselenggarakan di jalur pendidikan sekolah atau di jalur pendidikan luar sekolah.

2) Pendidikan dasar

Menurut PP No. 28 tahun 1990 dalam (Kunaryo,2000) pendidikan dasar adalah pendidikan umum yang lamanya sembilan tahun. Diselengarakan selama enam tahun di sekolah dasar dan tiga tahun di sekolah menengah lanjutan tingkat pertama atau satuan pendidikan yang sederajat. Tujuan pendidikan dasar adalah untuk memberikan bekal kemampuan dasar kepada peserta didik untuk mengembangkan kehidupan sebagai pribadi anggota masyarakat, warga Negara dan anggota umat manusias serta mempersiapkan peserta didik untuk mengikuti pendidikan menengah.

3) Pendidikan Menegah

Menurut PP No. 29 tahun 1990 dalam (Kunaryo,2000), pendidikan menengah adalah pendidikan yang diselenggarakan bagi pendidikan dasar. Bentuk satuan pendidikan yang terdiri atas: Sekolah Menengah Umum, Sekolah Menengah Kejuruan, Sekolah Menengah Keagamaan, Sekolah Menengah Kedinasan, dan Sekolah Menengah Luar Biasa.

4) Pendidikan Tinggi

Menurut UU No. 2 tahun 1989 dalam (Kunaryo,2000), pendidikan tinggi merupakan kelanjutan pendidikan menengah yang diselenggarakan untuk 
menyiapkan peserta didik menjadi anggota masyarakat yang memiliki kemampuan akademik atau professional yang dapat menerapkan, mengembangkan, atau menciptakan ilmu pengetahuan, teknologi, dan kesenian. Satuan pendidikan yang menyelenggarakan pendidikan tinggi disebut perguruan tinggi, yang dapat berbentuk akademi, politeknik, sekolah tinggi, institut atau universitas. Dalam penelitian ini untuk mengetahui tingkat pendidikan orang tua selain dilihat dari jenjangnya juga dapat dilihat dari tahun sukses atau lamanya orang tua sekolah. Semakin lama orang tua bersekolah berarti semakin tinggi jenjang pendidikannya. Contohnya, orang tua yang hanya sekolah 6 tahun berarti hanya sekolah sampai SD berbeda dengan orang yang sekolahnya sampai 12 tahun berarti lulusan SMA. Tingkat pendidikan yang pernah ditempuh orang tua berpengaruh pada kelanjutan sekolah anak mereka. Orang tua yang memiliki pendidikan yang tinggi mempunyai dorongan atau motivasi yang besar untuk menyekolahkan anak mereka.

b. Pendapatan

Pendapatan adalah jumlah semua pendapatan kepala keluarga maupun anggota keluarga lainnya yang diwujudkan dalam bentuk uang dan barang. Berdasarkan jenisnya, Biro Pusat Statistik membedakan pendapatan menjadi dua yaitu:

1) Pendapatan berupa barang

Pendapatan berupa barang merupakan segala penghasilan yang bersifat regular dan biasa, demikian juga penerimaan barang secara cuma-cuma, pembelian barang dan jasa dengan harta subsidi atau reduksi dari majikan merupakan pendapatan berupa barang.

2) Pendapatan berupa uang

Berdasarkan bidang kegiatannya, pendapatan meliputi pendapatan sektor formal dan pendapatan sektor informal. Pendapatan sektor formal adalah segala penghasilan baik berupa barang atau uang yang bersifat regular dan diterimakan biasanya balas jasa atau kontrasepsi di sektor formal yang terdiri dari pendapatan berupa uang, meliputi: gaji, upah dan hasil infestasi dan pendapatan berupa barang-barang meliputi: beras, pengobatan, transportasi, perumahan, maupun yang berupa rekreasi. 
Pendapatan sektor informal adalah segala penghasilan baik berupa barang maupun uang yang diterima sebagai balas jasa atau kontraprestasi di sektor informal yang terdiri dari pendapatan dari hasil infestasi, pendapatan yang diperoleh dari keuntungan sosial, dan pendapatan dari usaha sendiri, yaitu hasil bersih usaha yang dilakukan sendiri, komisi dan penjualan dari hasil kerajinan rumah. Dalam penelitian ini yang dimaksud dengan pendapatan orang tua adalah penghasilan berupa uang yang diterima sebagai balas jasa dari kegiatan baik dari sektor formal dan informal selama satu bulan dalam satuan rupiah. Besar kecilnya pendapatan yang diterima oleh setiap penduduk akan berbeda antara yang satu dengan yang lain, hal ini karena dipengaruhi oleh keadaan penduduk sendiri dalam melakukan berbagai macam kegiatan seharihari. Menurut (Sumardi dalam Yerikho,2007) mengemukakan bahwa pendapatan yang diterima oleh penduduk akan dipengaruhi oleh tingkat pendidikan yang dimilikinya. Dengan pendidikan yang tinggi mereka akan dapat memperoleh kesempatan yang lebih luas untuk mendapatkan pekerjaan yang lebih baik disertai pendapatan yang lebih besar. Sedangkan bagi penduduk yang berpendidikan rendah akan mendapat pekerjaan dengan pendapatan yang kecil

3) Pemilikan Kekayaan atau Fasilitas.

Pemilikan kekayaan atau fasilitas adalah kekayaan dalam bentuk barangbarang dimana masih bermanfaat dalam menunjang kehidupan ekonominya. Fasilitas atau kekayaan itu antara lain:

1) Barang-barang berharga

Dalam berbagai bentuk dan ukuran seperti perhiasan, televisi, kulkas dan lain-lain dapat menunjukkan adanya pelapisan dalam masyarakat.

2) Jenis-jenis kendaraan pribadi.

Kendaraan pribadi dapat digunakan sebagai alat ukur tinggi rendahnya tingkat sosial ekonomi orang tua. Misalnya: orang yang mempunyai mobil akan merasa lebih tinggi tingkat sosial ekonominya dari pada orang yang mempunyai sepeda motor. 
3) Jenis tempat tinggal.

untuk mengukur tingkat sosial ekonomi seseorang dari rumahnya, dapat dilihat dari: 1) Status rumah yang ditempati, bisa rumah sendiri, rumah dinas, menyewa, menumpang pada saudara atau ikut orang lain, 2) Kondisi fisik bangunan, dapat berupa rumah permanen, kayu dan bambu. Keluarga yang keadaan sosial ekonominya tinggi, pada umumnya menempati rumah permanent, sedangkan keluarga yang keadaan sosial ekonominya menengah kebawah menggunakan semi permanen atau tidak permanen, 3) Besarnya rumah yang ditempati, semakin luas rumah yang ditempati pada umunya semakin tinggi tingkat sosial ekonominya.

Rumah dapat mewujudkan suatu tingkat sosial ekonomi bagi keluarga yang menempati. Apabila rumah tersebut berbeda dalam hal ukuran dan kualitas rumah. Rumah yang dengan ukuran besar, permanen dan milik pribadi dapat menunjukkan bahwa kondisi sosial ekonominya tinggi berbeda dengan rumah yang keil, semi permanen dan menyewa menunjukkan bahwa kondisi sosial ekonominya rendah.

\subsection{Motivasi Belajar}

Melakukan perbuatan mengajar secara relative tidak semudah melakukan kebiasaan yang rutin dilakukan. Oleh karena itu diperlukan adanya sesuatu yang mendorong kegiatan agar semua tujuan yang diinginkan dapat tercapai. Hal tersebut adalah adanya motivasi. Menurut (Oemar Hamalik,2009 ) motivasi dipandang sebagai suatu proses.

Menurut Mc Donald yang di kutip oleh( Oemar Hamalik,2009) "Motivation is an energy charge within the person characterized by affective arousal and anticipatory goal reaction”, yang dapat diartikan bahwa motivasi adalah suatu perubahan energy dalam diri ( pribadi) seseorang yang ditandai dengan timbulnya perasaan dan reaksi untuk mencapai tujuan.Sedangkan menurut winkel motivasi adalah motif yang sudah menjadi aktif pada saat - saat melakukan percobaan, sedangkan motif sudah ada dalam diri seseorang jauh sebelum orang itu melalkukan suatu perbuatan. Menurut ( Nasution,2000) motivasi adalah segala daya yang mendorong seseorang untuk melakukan sesuatu. 


\subsection{Hipotesis Penelitian}

Hipotesis yang diuji dalam penelitian ini dirumuskan sebagai berikut:

1. $\mathrm{H}_{0}$ : Tidak terdapat pengaruh langsung kondisi sosial ekonomi terhadap prestasi belajar mahasiswa.

$\mathrm{H}_{1}$ : Terdapat pengaruh langsung kondisi sosial ekonomi terhadap prestasi belajar mahasiswa.

2. $\mathrm{H}_{0}$ : Tidak terdapat pengaruh langsung motivasi belajar terhadap prestasi belajar mahasiswa.

$\mathrm{H}_{1}$ : Terdapat pengaruh langsung motivasi belajar terhadap prestasi belajar mahasiswa.

3. $\mathrm{H}_{0}$ : Tidak terdapat pengaruh langsung kondisi sosial ekonomi terhadap motivasi belajar mahasiswa.

$\mathrm{H}_{1}$ : Terdapat pengaruh langsung kondisi sosial ekonomi terhadap motivasi belajar mahasiswa.

\section{METODOLOGI PENELITIAN}

Metode penelitian yang digunakan dalam penelitian ini adalah metode survei kausal dengan teknik analisis jalur (path analysis), dimana konstelasi masalahnya dapat dilihat pada diagram jalur berikut ini.

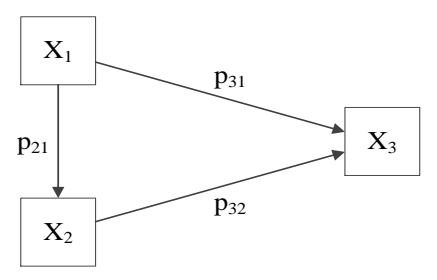

Gambar III.1 Diagram Jalur

Keterangan:

$\mathrm{X}_{1}=$ Kondisi Sosial Ekonomi.

$\mathrm{X}_{2}=$ Motivasi Belajar.

$\mathrm{X}_{3}=$ Prestasi Belajar Mahasiswa.

$\mathrm{p}_{31}=$ Koefisien jalur (pengaruh) variabel $\mathrm{X}_{1}$ terhadap $\mathrm{X}_{3}$.

$\mathrm{p}_{32}=$ Koefisien jalur (pengaruh) variabel $\mathrm{X}_{2}$ terhadap $\mathrm{X}_{3}$. 
$\mathrm{p}_{21}=$ Koefisien jalur (pengaruh) variabel $\mathrm{X}_{1}$ terhadap $\mathrm{X}_{2}$.

Penelitian dilakukan di Institut Sains dan Teknologi Al-Kamal Jakarta, sehingga populasi target dalam penelitian ini adalah seluruh mahasiswanya, sedangkan populasi terjangkaunya adalah seluruh mahasiswa Program Studi Teknik Informatika, Fakultas Teknologi Informasi \& Komunikasi Visual. Dari populasi terjangkau tersebut, diambil sampel sebanyak 70 mahasiswa dengan teknik simple random sampling.

Data penelitian dijaring melalui instrumen penelitian berupa seperangkat kuesioner yang disusun dalam bentuk butir-butir pernyataan dengan menggunakan skala Likert. Data yang terjaring diolah dan dianalisis dengan mengunakan program SPSS dan Amos, yang terdiri dari:

1. Uji Normalitas Data

Dalam pengujian tersebut digunakan uji Kolmogorov-Smirnov $Z$ dengan kriteria pengujian sebagai berikut:

a. Jika nilai Asymp. Sig. (2-tailed) > 0,01 maka data berdistribusi normal.

b. Jika nilai Asymp. Sig. (2-tailed) < 0,01 maka data tidak berdistribusi normal.

2. Uji Signifikansi Koefisien Korelasi

Koefisien korelasi yang digunakan adalah Pearson Correlation dengan kriteria pengujian signifikansinya sebagai berikut:

a. Jika nilai Sig. (2-tailed) > 0,01 maka koefisien korelasi tidak signifikan.

b. Jika nilai Sig. (2-tailed) < 0,01 maka koefisien korelasi signifikan.

3. Uji Signifikansi Regresi

Dalam pengujian tersebut digunakan uji $F$ (ANOVA) dengan kriteria pengujian sebagai berikut:

a. Jika nilai Sig. > 0,01 maka regresi tidak signifikan.

b. Jika nilai Sig. < 0,01 maka regresi signifikan.

4. Uji Linieritas Regresi

Dalam pengujian tersebut digunakan uji $F$ (ANOVA) dengan kriteria pengujian sebagai berikut:

a. Jika nilai Sig. (Deviation from Linearity) > 0,01 maka regresi linier.

b. Jika nilai Sig. (Deviation from Linearity) $<0,01$ maka regresi tidak linier.

5. Uji Signifikansi Koefisien Jalur 
Uji tersebut digunakan untuk menguji hipotesis penelitian 1, 2, dan 3 dengan kriteria pengambilan keputusan sebagai berikut:

a. Jika nilai $\mathrm{p}_{\mathrm{ij}}<0,05$ (koefisien jalur $\mathrm{p}_{\mathrm{ij}}$ tidak signifikan) maka $\mathrm{H}_{0}$ diterima dan $\mathrm{H}_{1}$ ditolak.

b. Jika nilai $\mathrm{p}_{\mathrm{ij}}>0,05$ (koefisien jalur $\mathrm{p}_{\mathrm{ij}}$ signifikan) maka $\mathrm{H}_{0}$ ditolak dan $\mathrm{H}_{1}$ diterima.

\section{HASIL PENELITIAN}

\section{Uji Normalitas Data}

Hasil uji normalitas data dapat dilihat pada tabel berikut ini.

Tabel IV.1

\section{Hasil Uji Normalitas Data}

\begin{tabular}{ccc}
\hline & $\begin{array}{c}\text { Kolmogorov- } \\
\text { Smirnov Z }\end{array}$ & $\begin{array}{c}\text { Asymp. Sig. } \\
\text { (2-tailed) }\end{array}$ \\
\hline X1 & 1,400 &, 040 \\
X2 &, 538 &, 934 \\
X3 &, 827 &, 500 \\
\hline
\end{tabular}

Dari hasil uji Kolmogorov-Smirnov pada Tabel IV.1, diperoleh nilai-nilai Asymp. Sig. (2-tailed) yang lebih besar dari 0,01 sehingga dapat disimpulkan bahwa data yang digunakan, baik data variabel $X_{1}, X_{2}$, maupun $X_{3}$, ketiganya berdistribusi normal.

\section{Uji Signifikansi Koefisien Korelasi}

Hasil uji signifikansi koefisien korelasi dapat dilihat pada tabel berikut ini.

Tabel IV.2

Hasil Uji Signifikansi Koefisien Korelasi

\begin{tabular}{cccc}
\hline & & $\begin{array}{c}\text { Pearson } \\
\text { Correlation }\end{array}$ & $\begin{array}{c}\text { Sig. } \\
(2-\text { tailed })\end{array}$ \\
\hline \multirow{2}{*}{ X1 } & X2 &, 497 &, 000 \\
& X3 &, 307 &, 009 \\
\hline \multirow{2}{*}{ X2 } & X1 &, 497 &, 000 \\
& X3 &, 649 &, 000 \\
\hline \multirow{2}{*}{ X3 } & X1 &, 307 &, 009 \\
& X2 &, 649 &, 000 \\
\hline
\end{tabular}

Dari hasil uji signifikansi koefisien korelasi (Pearson Correlation) pada tabel Tabel IV.2, diperoleh nilai-nilai Sig. (2-tailed) yang lebih kecil dari 0,01 sehingga dapat disimpulkan:

a. Koefisien korelasi antara $X_{1}$ dengan $X_{2}$ sebesar 0,497 adalah signifikan.

b. Koefisien korelasi antara $X_{1}$ dengan $X_{3}$ sebesar 0,307 adalah signifikan. 
c. Koefisien korelasi antara $\mathrm{X}_{2}$ dengan $\mathrm{X}_{3}$ sebesar 0,649 adalah signifikan.

\section{Uji Signifikansi Regresi}

a. Variabel $\mathrm{X}_{3}$ atas $\mathrm{X}_{1}$

Hasil uji signifikansi regresi variabel $\mathrm{X}_{3}$ atas $\mathrm{X}_{1}$ dapat dilihat pada tabel berikut ini.

\section{Tabel IV.3}

Hasil Uji Signifikansi Regresi Variabel $\mathbf{X}_{3} \operatorname{Atas} \mathbf{X}_{1}$

\begin{tabular}{lccc}
\hline & Regression & Residual & Total \\
\hline Sum of & 1194,213 & 11476,772 & 12670,986 \\
Squares & & & \\
df & 1 & 68 & 69 \\
Mean & 1194,213 & 168,776 & \\
Square & & & \\
F & 7,076 & & \\
Sig. &, 009 & & \\
\hline
\end{tabular}

Dari hasil uji signifikansi regresi pada Tabel IV.3, diperoleh nilai Sig. $=0,009<$ 0,01 sehingga dapat disimpulkan bahwa regresi variabel $\mathrm{X}_{3}$ atas $\mathrm{X}_{1}$ adalah signifikan.

b. Variabel $\mathrm{X}_{3}$ atas $\mathrm{X}_{2}$

Hasil uji signifikansi regresi variabel $X_{3}$ atas $X_{2}$ dapat dilihat pada tabel berikut ini.

Tabel IV.4

Hasil Uji Signifikansi Regresi Variabel $\mathrm{X}_{3} \operatorname{Atas} \mathrm{X}_{2}$

\begin{tabular}{lccc}
\hline & Regression & Residual & Total \\
\hline $\begin{array}{l}\text { Sum of } \\
\text { Squares }\end{array}$ & 5329,376 & 7341,609 & 12670,986 \\
df & 1 & 68 & 69 \\
Mean & 5329,376 & 107,965 & \\
Square & 49,362 & & \\
F & 4900 & & \\
Sig. &, 000 & \\
\hline
\end{tabular}

Dari hasil uji signifikansi regresi pada Tabel IV.4, diperoleh nilai Sig. $=0,000<$ 0,01 sehingga dapat disimpulkan bahwa regresi variabel $X_{3}$ atas $X_{2}$ adalah signifikan.

c. Variabel $\mathrm{X}_{2}$ atas $\mathrm{X}_{1}$

Hasil uji signifikansi regresi variabel $\mathrm{X}_{2}$ atas $\mathrm{X}_{1}$ dapat dilihat pada tabel berikut ini. 
Tabel IV.5

Hasil Uji Signifikansi Regresi Variabel $\mathbf{X}_{2} \operatorname{Atas} \mathbf{X}_{1}$

\begin{tabular}{lccc}
\hline & Regression & Residual & Total \\
\hline $\begin{array}{l}\text { Sum of } \\
\text { Squares }\end{array}$ & 4122,236 & 12597,250 & 16719,486 \\
df & 1 & 68 & 69 \\
Mean & 4122,236 & 185,254 & \\
Square & 22,252 & & \\
F & , & & \\
Sig. & & & \\
\hline
\end{tabular}

Dari hasil uji signifikansi regresi pada Tabel IV.5, diperoleh nilai Sig. $=0,000<0,01$ sehingga dapat disimpulkan bahwa regresi variabel $\mathrm{X}_{2}$ atas $\mathrm{X}_{1}$ adalah signifikan.

\section{Uji Linieritas Regresi}

a. Variabel $\mathrm{X}_{3}$ atas $\mathrm{X}_{1}$

Hasil uji linieritas regresi variabel $\mathrm{X}_{3}$ atas $\mathrm{X}_{1}$ dapat dilihat pada tabel berikut.

\section{Tabel IV.6}

\section{Hasil Uji Linieritas Regresi Variabel $\mathbf{X}_{3}$ Atas $X_{1}$}

\begin{tabular}{|c|c|c|c|c|c|}
\hline & \multicolumn{5}{|c|}{$\mathrm{X} 3 * \mathrm{X} 1$} \\
\hline & \multicolumn{3}{|c|}{ Between Groups } & \multirow{2}{*}{$\begin{array}{l}\text { Within } \\
\text { Groups }\end{array}$} & \multirow[b]{2}{*}{ Total } \\
\hline & (Combined) & Linearity & $\begin{array}{l}\text { Deviation } \\
\text { from } \\
\text { Linearity }\end{array}$ & & \\
\hline $\begin{array}{l}\text { Sum of } \\
\text { Squares }\end{array}$ & 4290,307 & 1194,213 & 3096,094 & 8380,679 & 12670,986 \\
\hline $\mathrm{df}$ & 30 & 1 & 29 & 39 & 69 \\
\hline $\begin{array}{l}\text { Mean } \\
\text { Square }\end{array}$ & 143,010 & 1194,213 & 106,762 & 214,889 & \\
\hline $\mathrm{F}$ & ,666 & 5,557 & ,497 & & \\
\hline Sig. & 875 & ,024 & ,973 & & \\
\hline
\end{tabular}

Dari hasil uji linieritas regresi pada Tabel IV.6, diperoleh nilai Sig. (Deviation from Linearity) $=0,973>0,01$ sehingga dapat disimpulkan bahwa regresi variabel $\mathrm{X}_{3}$ atas $\mathrm{X}_{1}$ adalah regresi linier.

b. Variabel $\mathrm{X}_{3}$ atas $\mathrm{X}_{2}$

Hasil uji linieritas regresi variabel $\mathrm{X}_{3}$ atas $\mathrm{X}_{2}$ dapat dilihat pada tabel berikut.

Tabel IV.7

Hasil Uji Linieritas Regresi Variabel $\mathbf{X}_{3}$ Atas $X_{2}$

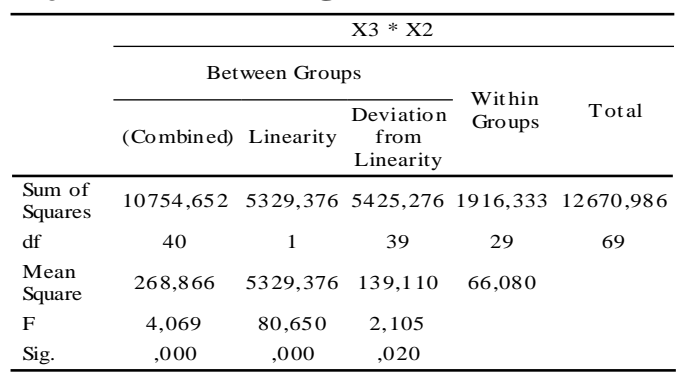


Dari hasil uji linieritas regresi pada Tabel IV.7, diperoleh nilai Sig. (Deviation from Linearity) $=0,020>0,01$ sehingga dapat disimpulkan bahwa regresi variabel $\mathrm{X}_{3}$ atas $\mathrm{X}_{2}$ adalah regresi linier.

c. Variabel $\mathrm{X}_{2}$ atas $\mathrm{X}_{1}$

Hasil uji linieritas regresi variabel $\mathrm{X}_{2}$ atas $\mathrm{X}_{1}$ dapat dilihat pada tabel berikut.

\section{Tabel IV.8}

Hasil Uji Linieritas Regresi Variabel $\mathrm{X}_{2} \operatorname{Atas} \mathrm{X}_{1}$

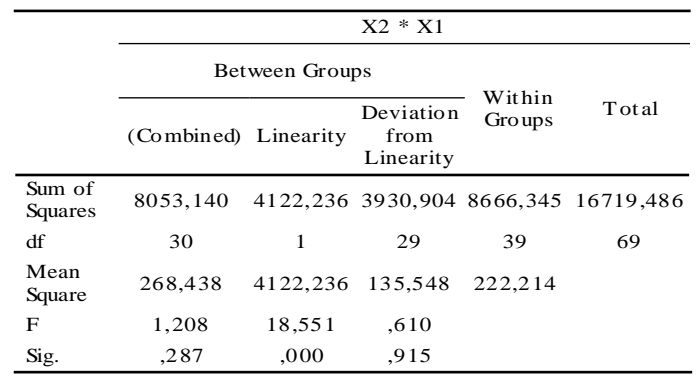

Dari hasil uji linieritas regresi pada Tabel IV.8, diperoleh nilai Sig. (Deviation from Linearity) $=0,915>0,01$ sehingga dapat disimpulkan bahwa regresi variabel $X_{2}$ atas $X_{1}$ adalah regresi linier.

\section{Uji Signifikansi Koefisien Jalur (Uji Hipotesis Penelitian)}

Hasil perhitungan koefisien jalur dengan menggunakan program Amos dapat dilihat pada gambar berikut ini.

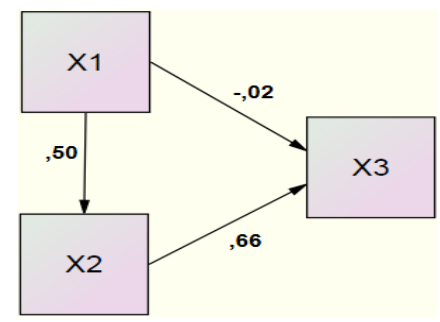

Gambar IV.1 Hasil Perhitungan Koefisien Jalur

a. Uji hipotesis penelitian 1

Karena nilai koefisien jalur $\mathrm{p}_{31}=-0,02<0,05$ (koefisien jalur tidak signifikan) maka keputusan yang diambil dalam pengujian hipotesis penelitian 1 adalah $\mathrm{H}_{0}$ diterima dan $\mathrm{H}_{1}$ ditolak, sehingga dapat dinyatakan bahwa tidak terdapat pengaruh langsung kondisi sosial ekonomi terhadap prestasi belajar mahasiswa.

b. Uji hipotesis penelitian 2

Karena nilai koefisien jalur $\mathrm{p}_{32}=0,66>0,05$ (koefisien jalur signifikan) maka keputusan yang diambil dalam pengujian hipotesis penelitian 2 adalah $\mathrm{H}_{0}$ 
ditolak dan $\mathrm{H}_{1}$ diterima, sehingga dapat dinyatakan bahwa terdapat pengaruh langsung motivasi belajar terhadap prestasi belajar mahasiswa.

c. Uji hipotesis penelitian 3

Karena nilai koefisien jalur $\mathrm{p}_{21}=0,50>0,05$ (koefisien jalur signifikan) maka keputusan yang diambil dalam pengujian hipotesis penelitian 3 adalah $\mathrm{H}_{0}$ ditolak dan $\mathrm{H}_{1}$ diterima, sehingga dapat dinyatakan bahwa terdapat pengaruh langsung kondisi sosial ekonomi terhadap motivasi belajar mahasiswa.

\section{KESIMPULAN DAN SARAN}

Berdasarkan pembahasan hasil penelitian, maka dapat ditarik kesimpulan sebagai berikut:

1. Kondisi sosial ekonomi berpengaruh langsung terhadap motivasi belajar mahasiswa Institut Sains dan Teknologi Al-Kamal Jakarta.

2. Motivasi belajar berpengaruh langsung terhadap prestasi belajar mahasiswa Institut Sains dan Teknologi Al-Kamal Jakarta.

3. Kondisi sosial ekonomi berpengaruh secara tidak langsung terhadap prestasi belajar mahasiswa Institut Sains dan Teknologi Al-Kamal Jakarta, yaitu melalui jalur motivasi belajar.

Dari kesimpulan di atas, maka peneliti memberikan saran-saran sebagai berikut:

1. Sivitas akademika Institut Sains dan Teknologi Al-Kamal Jakarta, khususnya dosen dan juga orang tua mahasiswa hendaknya menyadari akan pentingnya faktor motivasi belajar yang mempunyai pengaruh secara langsung serta faktor kondisi sosial ekonomi yang mempunyai pengaruh secara tidak langsung terhadap prestasi belajar mahasiswa.

2. Dosen dan orang tua mahasiswa Institut Sains dan Teknologi Al-Kamal Jakarta hendaknya secara bersama-sama untuk meningkatkan motivasi belajar mahasiswa agar prestasi belajarnya dapat meningkat seiring dengan meningkatnya motivasi belajarnya.

3. Orang tua mahasiswa hendaknya menyadari akan pentingnya faktor kondisi sosial ekonomi yang mempunyai pengaruh secara langsung terhadap motivasi belajar mahasiswa dan berupaya meningkatkan kondisi sosial ekonominya agar motivasi belajar mahasiswa dapat meningkat sehingga prestasi belajarnya dapat meningkat. 


\section{DAFTAR PUSTAKA}

Abdulsyani, 1994. Sosiologi Skematika, Teori dan Terapan. Jakarta: Bumi Aksara.

Hamalik, Oemar. 2003. Kurikulum dan Pembelajaran. Jakarta: Bumi Aksara

S, Nasution.2008. Berbagai Pendekatan dalam proses belajar dan mengajar. Jakarta: Bumi ksara

Santrock, John W. 2004. Educational Psychology. Boston: McGraw-Hill Higher Education.

Sardiman, A.M. 2001. Interaksi dan Motivasi Belajar Mengajar. Jakarta: Raja Grafindo.

Slameto. 2010. Belajar dan Faktor-Faktor yang Mempengaruhinya. Jakarta: Rineka Cipta.

Tu'u, Tulus. 2004. Peran Disiplin Pada Perilaku dan Prestasi Siswa. Jakarta: Grasindo.

Winkel, W. S. 2004. Psikologi Pengajaran. Yogyakarta: Media Abadi.

Woolfolk, Anita. 2007. Educational Psychology. Boston: Pearson Education, Inc.

Hadikusumo,Kunaryo.1995. Pengantar Pendidikan.Semarang:IKIP Semarang Press. 